\title{
Racism and Stereotyping of Refugees: The Use of the Hashtag \#Aufschrei by Twitter Users in Germany
}

\author{
$1^{\text {st }}$ Nandita Adilfi Eti Riyadi \\ German Studies Program, Faculty of \\ Humanities, Universitas Indonesia, \\ Depok, Indonesia \\ nanditaadilfi@gmail.com
}

\author{
$2^{\text {nd }}$ Maria Regina Widhiasti* \\ Literature Department, Faculty of \\ Humanities, Universitas Indonesia, \\ Depok, Indonesia \\ m.regina@ui.ac.id
}

\begin{abstract}
This article analyzes the use of the hashtag \#Aufschrei from the end of February to the end of March 2019. On January 25, 2013 Anne Wizorek, a German feminist, initiated the idea of encouraging German women to use the hashtag \#Aufschrei to express their personal experiences of sexism and harassment, both verbal and sexual. The data used in this study are the 10 relevant tweets with the highest engagement scores, as reported by the Keyhole online tool. Based on their content, eight of the 10 tweets still adhered to Wizorek's initial intention, which was to bring attention to acts of violence against women and sexism. Further analysis, using the method of computer-mediated discourse analysis (CMDA) of the tweets, was applied to the data corpus. This showed that the hashtag \#Aufschrei was also used to promote racist views as well as in attempts to form a stereotype of refugees from Muslim majority countries as a group that commonly perpetrates violence toward women.
\end{abstract}

Keywords— \#Aufschrei, racism, Muslim refugees, refugees in Germany, stereotypes about refugees

\section{Introduction}

Social media has enabled its users to share, interact, and express their opinions. As of January 2019, there were 3.48 billion social media users in the world, an increase of $9 \%$ from the previous year. In Germany, as of January 2019, there were 38 million social media users, or $46 \%$ of the total of internet users. The average internet user spends more than an hour on social media per day [1]. From these data, it is clear that the number of social media users, both in Germany and worldwide, continues to increase significantly and has become an integral part of people's lives.

As social media has become one of the necessities of life, the boundaries between it and the real world become very thin. The relationship between the two enables social media to play a huge role as a driver of social change. One example is the case of the murderous assault on the editorial offices of the French satirical magazine Charlie Hebdo. After the attack, the slogan and hashtag \#jesuisCharlie (I am Charlie) were widely used on Twitter. Four days after the attack, four million people demonstrated in the streets of France holding pictures of Joaquim Roncin's logo of the slogan and shouting "Je suis Charlie" [2]. Some samples of tweets with the hashtag \#jesuischarlie show that affective reactions are the most commonly conveyed. In this context, affective reactions include pride, especially pride as French citizens, solidarity with the French state and its values, as well as solidarity and support for Charlie Hebdo, expressions of grief, and condolences to the victims of the attack [3].
On the one hand, the widespread use of the slogan "Je suis Charlie" showed solidarity with victims of the Charlie Hebdo office attacks, as well as opposition to terrorism. On the other hand, this event raised another issue, namely racism. Many people considered the caricatures of the Prophet Muhammad displayed by Charlie Hebdo to be a racist stereotype of Muslims. Accordingly, the hashtag \#jenesuispasCharlie (I am not Charlie) was used to counter the stereotype [2]. Apart from this controversy surrounding the caricatures of the Prophet Muhammad, a year after the Charlie Hebdo office attack, at least five social changes were taking place in France. These changes included increases in racism and Islamophobia, restrictions on civil liberties, a shift in French politics toward conservatism, increasing fears of terrorist activity, and threats to the freedom of the press [4].

Social media, especially Twitter, is often regarded as an online diary for its users. This platform also provides its users with a collective space to share and discuss personal experiences. Twitter users communicate through short posts, known as tweets, whose function varies according to need. Tweets may be used, for example, to upload something new or to share links, to send public tweets to other users via direct messages, or to forward tweets sent by others to all users on the followers list (retweet) [5]

For the convenience of users in searching for tweets with certain themes outside their network, Twitter has an element or marker called a hashtag [6]. The hashtag is a combination of the symbol "\#” with words or phrases, which is used to index keywords or topics as conversations that can be searched for on Twitter. The Twitter hashtag also allows users to follow topics of interest easily, as well as to convey their opinions on themes discussed in other tweets containing the same hashtag element [6]. The hashtag also plays a role in aggregating tweets with specific themes or events, allowing the same hashtag users to identify, discuss, and connect with each other. The development of 'hashtagging' practices by Twitter users to mark and categorize themes produces what Maireder and Ausserhofer [7] describe as theme networks-semantic networks represented in digital object text [8]. The motivation of Twitter users in tagging (hashtagging) is twofold, firstly for the purpose of structured archiving (organizational), as well as for social and communicative goals [9]. From these two motivations, others have also emerged, such as enabling future retrieval, contributing and sharing, attracting attention, playing and competing, self-presentation, and expressing opinions. 
The social and communicative motivation of a hashtag, especially for expressing opinions, is pertinent to the case of Anne Wizorek. The German feminist and activist initiated the use of the hashtag \#Aufschrei to campaign for awareness of sexual violence in everyday life. "We must gather our experiences in one hashtag. I suggest \#Aufschrei"- on the morning of January 25, 2013, Anne Wizorek sent this tweet and initiated a broad debate about sexism in everyday life in Germany [10]. As seen in data uploaded by www.mediamonitoring.de for the four day period from January 23 to January 27, 2013, the number of tweets using the hashtag \#Aufschrei increased dramatically, with more than 57,500 examples on January 25, 2013. Through this hashtag, German women expressed their resentment of physical, verbal, and sexual harassment, and of their day-today experience of sexual abuse.

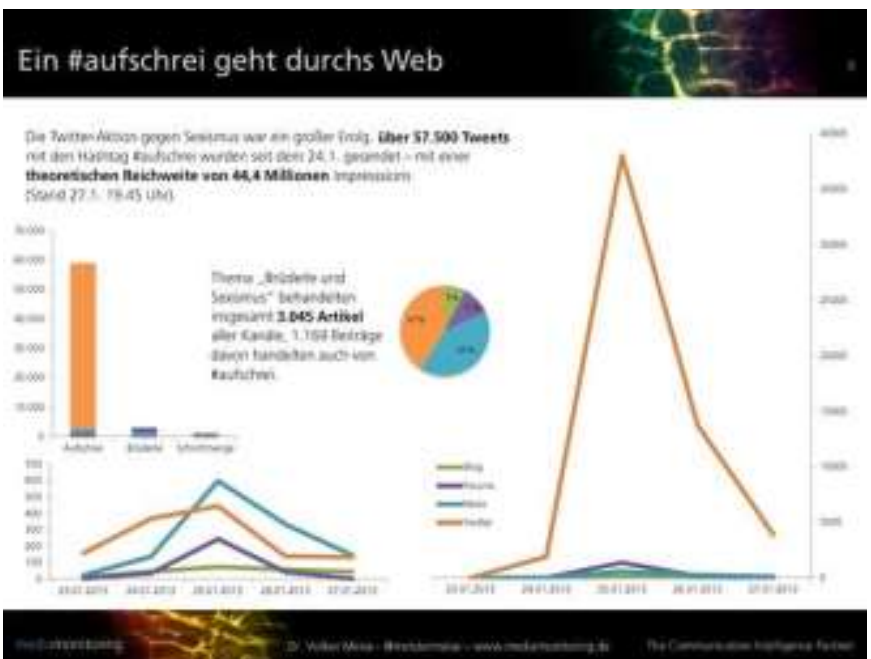

Figure 1. Graph of \#Aufschrei hashtag development on Twitter

The hashtag \#Aufschrei (outcry) is an example of German women using hashtagging to collect tweets on the theme of personal experience of sexual harassment. Social media platforms, such as Twitter, enable activists to carry out campaigns to fight harassment and raise awareness. In some cases, such campaigns have succeeded in drawing national attention to existing issues, and in motivating policy and political change [11]. The \#Aufschrei debate is an example of this. It began as a collection of personal experiences to raise awareness of daily sexism, which then broadened to a general consideration of gender relations and even of Twitter's importance in German society [8].

Hashtags related to feminist issues have been discussed widely in print media and television. In recent years, intense discussions about sexism and sexual violence have become a particularly prominent theme on Twitter and social media [10]. One example of using hashtags in this context is \#MeToo, which was created by African-American human rights activist Tarana Burke and popularized by Alyssa Milano, to encourage women around the world to communicate their experiences of sexual harassment. In the UK, the online site The Everyday Sexism Project became a key medium to publicize experiences of sexism, and provoked the hashtags \#shoutingback and \#EverydaySexism on Twitter, which spread internationally in April 2012 [10].
Maireder \& Schlögl [8] discuss \#Aufschrei and the development of a public discourse about day-to-day sexism in Germany. In this regard, tweets with the hashtag \#Aufschrei became a new way for feminists to protest against sexism [10]. The hashtag \#Aufschrei, coined by Anne Wizorek, was used as a form of activism on social media to campaign for feminism. Thus, social media provided a new venue for feminists to campaign on gender issues and on feminism. Moreover, social media provided feminists with a larger potential audience to achieve their goals [12].

Even five years after \#Aufschrei was initiated by Wizorek, the hashtag is still widely used on Twitter. While \#Aufschrei is still used to discuss problems faced by German women, it is no longer limited to revealing instances of sexual harassment. The hashtag has been applied to incidents of murder and violence, as well as the sexism experienced by German women. This evolution in the use of the \#Aufschrei hashtag is an interesting object of study since it shows the process of communication and conversation surrounding the issue of sexism and violence against women in German society.

\section{Method}

In order to analyze the shift in the meaning of the hashtag \#Aufschrei between 2013 and 2019, this study uses quantitative data on the hashtag's use on Twitter in early 2019. This quantitative data collection used an online tool called Keyhole to identify the 10 relevant tweets with the highest level of engagement. Engagement is a measure of the total number of user interactions with a given tweet. In this case, Keyhole's calculation is based on the number of tweets passed to other users (retweet). The timeframe under consideration for this study's purposes was from February 26 to March 26, 2019.

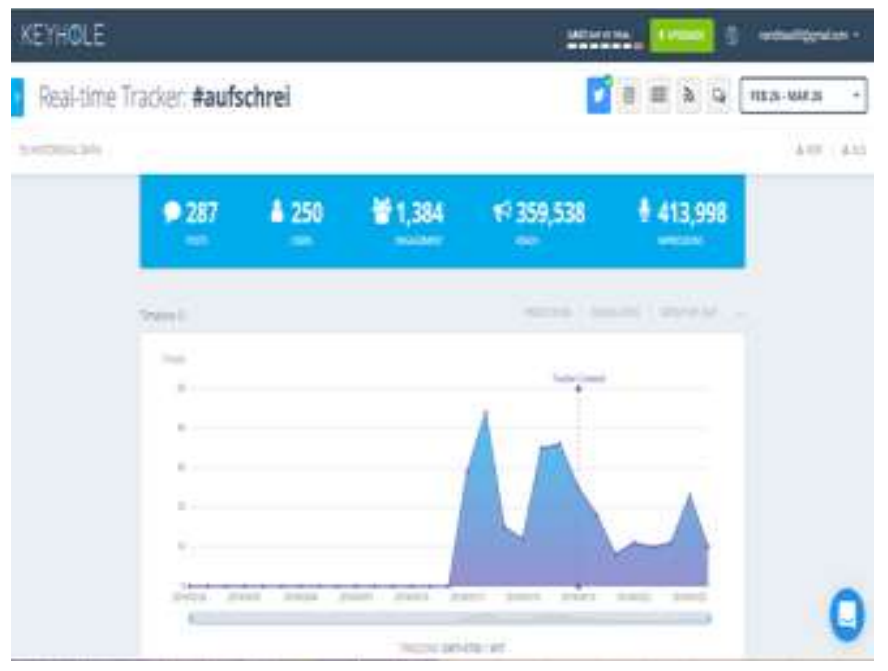

Figure 2. Graph of \#Aufschrei hashtag development on Twitter, February 26 - March 26, 2019

Within one month, 287 tweets with the hashtag \#Aufschrei were sent from 250 accounts. During this period, as shown in Figure 2, the use of \#Aufschrei experienced more fluctuations in March than in February. This is related to International Women's Day, which is celebrated on March 8. Based on an analysis of the corpus, it appears that 
\#Aufschrei hashtags are still used in connection with issues concerning women, feminism, and sexism experienced by women, even though a shift in meaning and toward discussion of broader issues was already apparent in January 2013. The 10 tweets with the highest level of engagement, which form the corpus of this study, can be seen in the following figure:

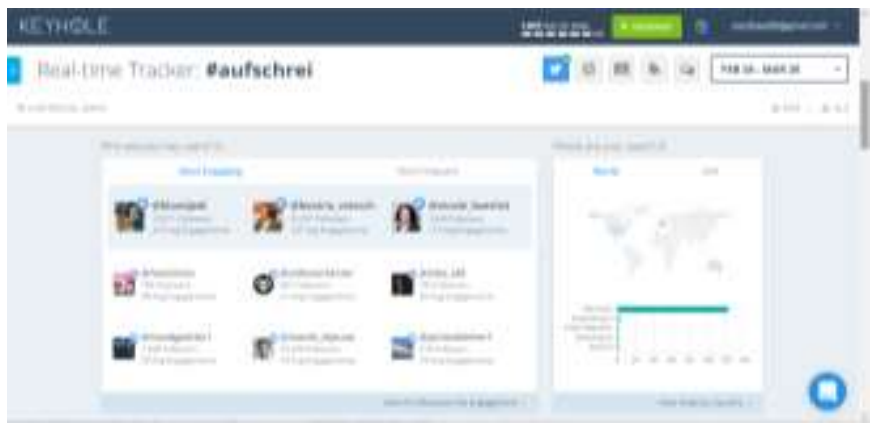

This corpus was analyzed using the Computer-Mediated Discourse Analysis (CMDA) method, which is a derivative of CDA (Critical Discourse Analysis). CMDA is used to analyze four levels of online media, namely structure, meaning, interaction management, and social phenomena. CMDA's goal is to adapt CDA, derived from the field of linguistics, to analyzing digital forms of discourse, such as social media. These methods and phenomena are combined with broader issues, then mapped onto a four level hierarchy, ranging from a micro-linguistic, contextindependent level, to the level of social phenomena contextualized at a macro scale [13].

At the structural level of CMDA, language in online discourse can be analyzed in terms of both typography and orthography.- The former concerns the use of punctuation (periods, commas, and spaces) and spelling (uppercase, sound absorption, writing with symbols and/or pictures, phonetic spelling, symbols and pictures (emoticons) [14]. The latter deals with the use of new word formations and sentence structure. In most cases, social media users will choose the appropriate words when typing, within the 280 character limit for a single tweet. Faced with this limit, users also use word abbreviations creatively to express selected words, and tend to employ short grammatical constructions. The second level (meaning) consists of the meaning of words, speech, etc. Meaning encompasses whatever the user wants to convey, and includes expression, through letters and symbols, that try to resemble facial expressions in order to complement the text of a message.

The third level (interaction management) includes features such as turn-taking and topic development. This refers to how multiple users coordinate the interactions that occur between them. The fourth and final level (social phenomena) includes linguistic expressions of status, conflict, negotiation, power, and face management. Face management theory is used to explain certain features of related communication phenomena such as language understanding, people's perceptions, and cross-cultural communication. The word "face" in this case is a metaphor for language [15]. Social factors and context in a text message can shape the function of the resulting discourse.

\section{Labeling Refugees: Racism Behind the \#Aufschrei Hashtag}

In accordance with Wizorek's initial idea of highlighting instances of sexism and violence against women, @ BlondJedi used \#Aufschrei to comment on the murder of a German woman named Susanna Feldmann. The suspect in Susanna's murder was a refugee from Iraq named Ali Bashar, often referred to as Ali B in various media. This tweet, sent on March 12, 2019, had the highest engagement among those retrieved, having been retweeted 656 times, and retweeted and favorited 1559 times. The level of engagement with this tweet may have been high because @BlondJedi sent the tweet on the trial date of Ali B. News articles uploaded by Zeit online confirm that, on March 12, 2019 in the Wiesbaden District Court, the defendant Ali B, a 22-yearold Iraqi refugee, admitted to killing a German woman named Susanna (14 years). Ali B was also accused of raping Susanna before killing her, an accusation which he denied. This murder, which occurred in early June 2018, triggered a political debate. On the one hand, various groups protested against sexual violence and against immigration in Mainz, while on the other hand, an alliance of organizations protested against racism in Germany's political asylum system.

Twitter user @BlondJedi discussed the murder of Susanna with reference to Ali B's sexist views about women or wives. The English translation of the tweet is as follows:

Iraqi "refugee" \#AliB is currently on trial for murdering \#Susanna. Ali B's answer about how a wife / woman should be:

- Not working, cleaning (home) + cooking

- Has no relationship with men

- Does not go to the street (outside the house)

- Virgin

Yes, now what (again), BessermenschInnen? \#Aufschrei or \#metoo?

The word BessermenschInnen is derived from the root word Bessermenschen, which is a compound of besser and Menschen. The word besser, which means "better", belongs to the adjective group (adjektiv), and is the comparative for gut (good). Meanwhile, the word Menschen means "human" or "person", and belongs to the group of nouns (nomen). The word der Mensch, plural form die Menschen, is a masculine noun, but in this context refers to "people" in general rather than not just men (der Mann). Nevertheless, German also recognizes the form of die Menschin (plural: die Menschinnen), though it is used far less than der Mensch. In German, the capital letter I in the suffix -Inen is written between lowercase letters. This is to indicate nouns that are related to people and are intended to include both men and women (gender-neutral). This is also called Binnen-I or Binnenmajuskel [16]. Therefore, the use of the word BessermenschInnen - which is the combination of the plural forms of die Menschen and die Menschinenn - shows the intention of @BlondJedi to avoid gender biased words. By using BessermenschInnen instead of the more common Bessermenschen, @BlondJedi establishes a position against various aspects of sexism, including language. 
The words BessermenschInnen or Bessermenschen do not have dictionary definitions. Bessermenschen may, however, be compared with the adjective Gutmenschen (good human), from which it is derived, and which the Duden dictionary defines as a naïve human being who is determined to show political correctness and who consequently behaves in ways that are considered uncritical, exaggerated, annoying, etc. In 2015, the word Gutmensch was named Unwort des Jahres (the worst word of the year). According to Nina Janich, a linguist who was a judge of Unwort des Jahres, in the debate about refugees, the terms "tolerance" and "help" were generally interpreted as ugly, stupid, or unworldly, and indicative of helper syndrome, or moral imperialism. As "good people" (Gutmensch), those who volunteer to help refugees or who oppose attacks on refugee homes are also criticized [17]. Opponents of migration now use the term "welcome culture" to condemn the pro-refugee camp and to push for policy restrictions. "Welcome culture" is a central term of right-wing populist discourse, comparable to the use of "good people" or "Gutmensch" [18]. Thus, while the word Bessermenschen can literally be parsed as "good person," in this context it is commonly associated with groups of people who are accepting of refugees in Germany.

Like@BlondJedi, @Nicole_Hoechst also sent a tweet related to crime by refugees. The tweet was sent on March 7, 2019, exactly one day before the commemoration of International Women's Day. The tweet was retweeted 115 times and favorited 161 times. Translated into English, it states: "after the recent killing of girls (in \#Worms) even on \#Frauentag (Women's Day) no \#Aufschrei? \#Rip! \#Kriegsverbrecher (War Criminals) / female killers among refugees, we always warned. However, is \#StarkeFrauenStarkeWirtschaft (strong women, strong economy) the top theme for March 8th? \#AfD \#Tunesier (Tunisian) \#Küchenmesser (Kitchen Knife)". This was a comment in response to a tweet from the account @Uwe_Junge_MdL, who wrote in German "young women killed by Tunisians! Perpetrators should be deported shortly after the suspension of deportation! \#Asylantrag (Asylum Request), \#Duldung (Suspension of Deportation) \#Mord (murder)! How often again? From the case \#Mia and \#Susanna did people not learn anything?" This tweet is a negative commentary on cases of murder of German women by foreign citizens. The \#Susanna hashtag also refers to the murder of Susanna Feldmann. In addition, the tweet was accompanied by a link to a news article uploaded by the online news site www.heidelberg24.de, entitled Tunesier tötet Freundin († 21) - zwei Tage vorher hätte er abgeschoben werden sollen (Tunisian citizen killed girlfriend $(† 21)$ - he should have been deported two days before). The article reported on the murder of a woman named Cynthia by her 22-year-old Tunisian boyfriend, using a kitchen knife. As the article elaborates, he had previously been involved in cases of physical violence, drugs, and coercion with threats.

Through her tweets, @Nicole_Hoescht directed criticism toward Twitter users in Germany who used the hashtag \#StarkeFrauenStarkeWirtschaft instead of \#Aufschrei on International Women's Day. The owner of the @Nicole_Hoechst account sees the use of the hashtags as a reflection of concern for an issue, and thus questions the priorities of Twitter users who focus on the role of women in the German economy rather than violence against women. Meanwhile, the @Uwe_Junge_MdL account wrote the phrase "How often again? From the case of \#Mia and \#Susanna did people not learn anything?" This creates the impression that crimes conducted by refugees against German women have been commonplace, while downplaying the crimes against German women committed by German citizens themselves. Based on data from the Bundeskriminalamt (German Federal Criminal Police Station) for 2018, the number of cases of homicide with suspects other than German male citizens was 310 , with 575 German female victims. Meanwhile, 436 male citizens were suspected of murdering German women [19]. The @Volksverherzer account replied to the@Nicole_Hoechst tweet with "I'm crying for \#Cynthia. Anyone who is now not voicing \#Aufschrei against illegal Muslim residents who commit crimes, and does not encourage exemplary activities such as \#Mädchenkongress (alternative women's congress) (held by the AfD party) (specifically against \#Mädchenmorde (murder of women)), you are guilty! \#Rip \#Worms \#Frauentag (Women's Day) \#AfD". This tweet also attaches an official poster of the AfD party (Alternative für Deutschland or Alternative for Germany). On the right side of the poster is a silhouette of the side of a man's face of a man, with a caption that means "But the crazy SPD warns about right-wing extremists: Tunisians kill a (female) 21year-old!" The SPD (Sozialdemokratische Partei Deutschlands or Social Democratic Party) is one of the parties in Germany that has been a major participant in the socio-political field [20]. The word "crazy" in the sentence on the poster should be seen as sarcasm, given that the SPD and AfD have opposing views toward immigrants. The SPD formed a coalition government with the CDU (Christlich Demokratische Union Deutschlands or Christian Democrats), the party of German chancellor Angela Merkel, with both supporting an open-door policy symbolizing Germany's openness to refugees. Meanwhile, the AfD is a right-wing party that is both anti-immigrant and anti-Islamic. Through this poster, the AfD expressed its criticism of the SPD, that refugees have a negative impact on German citizens. In addition, @Nicole_Hoechst indirectly reminded the German community to always be wary of refugees, on the grounds that these murders of German women by refugees were not the first to occur. In the context of the tweet posted by the @Nicole_Hoechst account, and the murders of girls in Worms, it is clear that women are subjected to violence, up to and including murder.

A tweet discussing the same event was sent by @ Hessinnen on International Women's Day itself, March 8, 2019. This was retweeted 60 times and liked 63 times. The tweet means "Recent murder of a girl (\#Cynthia, $† 21$, murdered by \#Tunesier (Tunisian man) with more than 10 stabbing wounds! \#Rip), desperate cry for help. We won't be silenced. Join \#Mädchenkongress (Women's Congress) on May 17! \#Frauentag (Women's Day) \#Weltfrauentag (International Women's Day) \#InternationalWomensDay \#Aufschrei \#AfD \#Worms \#Ahmed". Warnings against refugees are delivered in tweets that link refugee backgrounds with criminal acts. The use of terms like Islamische Illegale, Irakischer Flüchtling, and Tunesier, as pronouns for the perpetrators of the killings shows a deliberate attempt to establish a stereotype about refugees from countries with a majority Muslim population. 
The @BlondJedi account links the rape and murder of Susanna Feldmann with Ali Bashar's background as a refugee. This can be seen in the description of Ali Bashar as "irakischer Flüchtling," which highlights Ali's background in relation to his criminal acts. Ali's identity, as revealed by @BlondJedi, is factual; therefore, it has huge implications in the way the tweet's readers form opinions or assumptions. Ali's cultural background and identity as an Iraqi refugee is related to his views on the ideal behavior of a woman or wife. While these two things written by @BlondJedi about Ali Bashar are complementary, they do not demonstrate a causal relationship. This is an example of a correlational fallacy, in which the coincidence of two events is taken as evidence of a cause and effect relationship [21]. Through her tweets, @BlondJedi implies that Ali's sexist views about women or wives are a consequence of his identity as an Iraqi man, and that these views underlie his rape and murder of Susanna. Similar insinuations were made by @Uwe_Junge_MdL and @ Hessinnen in using the word Tunesier to refer to Ahmed T., the person who killed Cynthia.

The formation of a negative association with Islam was also carried out by the account @Volksverherzer, when the word islamisch (Islamic) was included in reference to criminelle Illegale (illegal immigrants who commit crimes). As when the pronouns irakischer Flüchtling and Tunesier were used to describe the perpetrators of murder, the addition of the word islamisch creates the impression of a causal relationship between an offender's religious background and his violent acts. Muslim immigrants in Germany (both immigrants and refugees) are not only labelled as perpetrators of killings, but are even equated with war criminals. This can be seen in the @Nicole_Hoechst tweet: "Kriegsverbrecher/Mädchenmörder unter Flüchtlingen, wir haben stets gewarnt". In her capacity as an AfD spokesperson, @Nicole_Hoechst said that the AfD had always warned the German people that there were war criminals and murderers of women among refugees. Through this tweet, @Nicole_Hoechst represents the views of the anti-immigrant AfD.

The positioning of the AfD as an anti-immigrant party was also shown by the @Nittom account whose tweet can be translated in English as "Congratulations, Merkel's Germany. You get exactly what you deserve. \#AliB \#alibashar \#Ali \#Susanna \#metoo \#Aufschrei". Like some of the tweets discussed earlier, @ nittom alludes to the murder of Susanna Feldmann. Like @BlondJedi, who directs her tweets to community groups that accept immigrants - using the word Bessermenschen-@ nittom clearly presents itself as an anti-immigrant party. In the tweet, @nittom uses the pronouns ihr people (you), which asserts a different position to its interlocutors, namely the people of Germany under Merkel's leadership. With the phrase "Merkel's Germany", this account refers to people who support the open-door policy maintained by Angela Merkel, i.e., people who are not anti-immigrant. Thus, this group of people must bear the consequences of welcoming refugees or immigrants by having a "female killer" living among them. Citing Bild's news article on Ali Bashar's opinions about the ideal woman [22], @ nittom warns that Bashar's perspective on women is likely common among refugees. This conservative view is, of course, something that is unusual, or even unacceptable, in
German society. By including Bashar's perspective on women, and contrasting it with the principle of equality between women and men, @nittom, indirectly forms an argument against immigrants and refugees.

\section{Conclusion}

Analysis of the corpus of 10 tweets using the hashtag \#Aufschrei with the most engagement in the one month period 26 February-26 March 2019 shows that, in most cases, the same meaning was intended as when it first appeared in 2013. This hashtag is still used to discuss violence against women, although it is no longer limited to instances of sexual harassment experienced by German women. Conversely, the use of \#Aufschrei outside the context of women and sexism can be seen in two of the 10 tweets. Both tweets use the literal meaning of the word Aufschrei, which is "shout". The first was a call to protest against German President Frank-Walter Steinmeier, who delivered a speech in which he expressed shame at the number of German people who still openly embraced antiSemitism. The second tweet uses \#Aufschrei to question the attitude of the CDU/CSU, and the German government, in openly accepting refugees.

Analysis of the tweets that formed the corpus of this study shows that there are efforts to encourage negative opinions about immigrants or refugees from Islamic countries as criminals with outdated attitudes toward women. This shows that anti-immigrant ideology - especially against individuals from Islamic countries - is still shared by many Twitter users from Germany. Although not explicitly mentioned, racist ideology is evident in the use of words and phrases that tend to be negatively associated with Islam. In addition, this research shows the use of stereotypes of Islam as a religion that limits and represses women, and that is synonymous with acts of terror (terrorist religion).

The use of \#Aufschrei by early 2019 had experienced a shift in function compared to early 2013 . When the hashtag first emerged, the focus of its use was on personal experiences of day-to-day sexual harassment and sexism by German women. By 2019, proponents of anti-immigrant and anti-refugee ideologies were exploiting the hashtag for their own purposes. This shift in the use of \#Aufschrei illustrates the situation in German society in early 2019, when the controversy surrounding refugees was a hot topic. This shows the dynamics of a social media discourse which reflects the current situation in German society.

The tweets that formed the corpus of this research are those with a high level of engagement between users. Thus, it can be assumed that the act of retweeting or liking tweets favoring anti-immigrant and anti-Islamic positions is a form of shared understanding with the senders of the tweets. In other words, the phenomenon of opposition to refugees from Islamic countries which occurred in Germany in early 2019 reflects that which occurred in France after the \#jesuischarlie movement. This can be seen from the growth in support for the AfD, a party which is openly anti-immigrant. Given recent events, the development of racist ideology and antiimmigrant views in Germany should be a focus of continuing research. 


\section{Closing}

This research would not have been possible without the online tool Keyhole. We are thankful to our friends and colleagues in the German Department, Faculty of Humanities, Universitas Indonesia. We are also immensely grateful to the Committee of INUSHARTS 4.0, who translated and moderated this paper, and thus improved the manuscript significantly.

\section{References}

[1] Moghaddam, Sheila. (2019). Social Media Statistiken 2019 in Deutschland. Hootsuite Inc, retrieved from April 1, 2019, at 14.36 WIB. https://blog.hootsuite.com/de/social-media-statistiken-2019-indeutschland/

[2] Devichand, Mukul. (2016). BBC Trending: How the world was changed by the slogan 'Je Suis Charlie. $B B C$, retrieved from May 10, 2018, at 10:40 WIB. https://www.bbc.com/news/blogstrending-35108339

[3] Payne, R. (2018). 'Je suis Charlie': Viral circulation and the ambivalence of affective citizenship. International Journal of Cultural Studies, 21(3), 277-292.

[4] Harris, Chris. (2016). Charlie Hebdo attacks: Five ways France has changed. Euronews, retrieved from May 18, 2019, at 22:39 WIB. https://www.euronews.com/2016/01/07/charlie-hebdoattacks-five-ways-france-has-changed

[5] Page, R. (2012). The linguistics of self-branding and microcelebrity in twitter: The role of hashtags. Discourse \& Communication, 6(2), 181-201. doi:10.1177/1750481312437441

[6] Giaxoglou, K. (2018). JeSuisCharlie? hashtags as narrative resources in contexts of ecstatic sharing. Discourse, Context \& Media, 22, 13-20. doi:10.1016/j.dcm.2017.07.006

[7] Ausserhofer, J., \& Maireder, A. (2013). National politics on Twitter: Structures and topics of a networked public sphere. Information, Communication \& Society, 16(3), 291-314. doi:10.1080/1369118X.2012.756050

[8] Maireder, A., \& Schlögl, S. (2014). 24 hours of an \#outcry: The networked publics of a socio-political debate. European Journal of Communication, 29(6), 687-702. doi:10.1177/0267323114545710

[9] Marlow, C., Naaman, M., Boyd, D., \& Davis, M. (2006). HT06, tagging paper, taxonomy, flickr, academic article, to read. Paper presented at the 31-40. doi:10.1145/1149941.1149949

[10] Drüeke, R., \& Zobl, E. (2016). Online feminist protest against sexism: The german-language hashtag \#Aufschrei. Feminist Media Studies, 16(1), 35-54.

[11] MacKinnon, R., Hickok, E., Bar, A., \& Lim, H. I. (2015). Fostering freedom online: The role of internet intermediaries. UNESCO Publishing.

[12] Carstensen, Tanja. (2013). Gender and social media: Sexism, empowerment, or the irrelevance of gender?. in Carter, Cynthia., Steiner, Linda., and McLaughlin, Lisa. (Ed.). The Routledge Companion to Media \& Gender (p. 483-492). London: Routledge.

[13] Herring, Susan. (2013). Discourse in web 2.0: Familiar, reconfigured, and emergent. 1-26.

[14] Suwardjono. (2008). Aspek Tipografi dalam Penulisan Karya Ilmiah/Akademik/Profesional. Yogyakarta: UGM

[15] Holtgraves, T. (1992). The linguistic realization of face management: Implications for language production and comprehension, person perception, and cross-cultural communication. Social Psychology Quarterly, 55(2), 141-159. Retrieved from http://www.jstor.org/stable/2786943

[16] Schoental, Gisela. (2000). Impulse der feministischen Linguistik für Sprachsystem und Sprachgebrauch. in Besch, Werner, et al. Sprachgeschichte: ein Handbuch zur Geschichte der deutschen Sprache und ihrer Erforschung. In: Band 2 von Handbücher zur Sprach- und Kommunikationswissenschaft (p. 2064-2100). Berlin: Walter de Gruyter GmbH.

[17] Wermelskirchen, Axel. (2016). „Unwort des Jahres“: Der gute alte Gutmensch ist zurück. Frankfurter Allgemeine Zeitung, retrieved from May 13, 2019, at 20:57 WIB.
[18] Trauner, F., \& Turton, J. (2017). "Welcome culture": The emergence and transformation of a public debate on migration. Österreichische Zeitschrift Für Politikwissenschaft, (1), 33-42. doi:http://remote-lib.ui.ac.id:2090/10.15203/ozp.1587.vol46iss1

[19] Bundeskriminalamt. (2019). Nichtdeutsche Tatverdächtige nach Alter und Geschlecht. Germany: BKA. Bundeskriminalamt. (2019). Deutsche Tatverdächtige nach Alter und Geschlecht. Germany: BKA.

[20] Knight, Benjamin. (2017). Yang Perlu Anda Ketahui Tentang Partai di Jerman. Deutsche Welle, retrieved from May 7, 2019, at 16:38 WIB. https://www.dw.com/id/yang-perlu-anda-ketahuitentang-partai-di-jerman/a-39162807

[21] Foresman, G. A., Fosl, P. S., \& Watson, J. C. (2016). The critical thinking toolkit. Hoboken: John Wiley \& Sons, Incorporated.

[22] Goedert, Lisa, et al. (2019). Ali Bashar gesteht Susannas (14) Ermordung, behauptet aber ,Ich kann mich nicht an den Vorfall erinnern“. Bild, retrieved from June 7, 2019, at 15:41 WIB. https://www.bild.de/regional/frankfurt/frankfurt-

aktuell/wiesbaden-susannas-killer-vor-gericht-ali-bashar-willaussagen-60614108.bild.html

[23] AFP, fo. (2019). Angeklagter gesteht Tötung von Susanna F. Zeit, retrieved from April 23, 2019, 05:44 WIB. https://www.zeit.de/gesellschaft/zeitgeschehen/2019-03/landgerichtwiesbaden-susanna-f-prozessbeginn-ali

[24] Chase, Jefferson. (2018). Pembunuhan Susanna Ungkap Kelemahan Sistem Suaka Politik Jerman. Deutsche Welle, retrieved from April 23, 2019, at 17:40 WIB. https://www.dw.com/id/pembunuhan-susanna-ungkap-kelemahansistem-suaka-politik-jerman/a-44154187

[25] Duden. (2013). Duden-Die deutsche Sprache. Berlin: Bibliographisches Institut.

[26] Eichelsheimer, Robin. (2019). Tödlicher Beziehungsstreit in Worms: Tunesier tötet Freundin $(\dagger 21)$ - zwei Tage vorher hätte er abgeschoben werden sollen. Heidelberg24, retrieved from May 10, 2019, at 12:40 WIB. https://www.heidelberg24.de/welt/wormsjunge-frau-freund-getoetet-taeter-haette-kurz-zuvor-abgeschobenwerden-sollen-zr-11833035.htm

[27] Herring, Susan. (2004). Computer-mediated discourse analysis: an approach to researching online communities. Designing for Virtual Communities in the Service of Learning. 316-338. 10.1017/CBO9780511805080.016.

[28] Jatmika, Aningtias. (2018, October 19). Burkini, Solution for muslim Girl in Swimming Lessons. Tempo, retrieved from May 1, 2019, at 23:57 WIB. https://en.tempo.co/read/513107/burkinisolution-for-muslim-girl-in-swimming-lessons

[29] Kailitz, Susanne. (2019, March 15). Fraktionen wollen mehr Gleich-stellung für Frauen. Deutscher Bundestag, retrieved from May 19, 2019, at 11:49 WIB. https://www.bundestag.de/dokumente/textarchiv/2019/kw11-deinternationaler-frauentag-595210

[30] Kämper, Vera. (2013). \#Aufschrei auf Twitter: "Männer nehmen den alltäglichen Sexismus gar nicht wahr". Spiegel, retrieved from

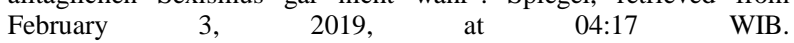
http://www.spiegel.de/panorama/gesellschaft/aufschrei-interview-zursexismus-debatte-auf-twitter-a-879729.html

[31] Kamus. (2016). Pada KBBI Daring. Retrieved from April 4, 2019, at 16:58 WIB. https://kbbi.kemdikbud.go.id/entri/ortografi

[32] MDR. (2019). Mindestens 20 Tote bei Anschlag auf Kirche. Mitteldeutscher Rundfunk, retrieved from May 19, 2019, at 05:37 WIB. https://www.mdr.de/nachrichten/politik/ausland/anschlagphilippinen-100.html

[33] Sanders, James., \& Patterson, Dan. (2019). Facebook data privacy scandal: A cheat sheet. TechRepublic, retrieved from June 7, 2019, at 13:46 WIB. https://www.techrepublic.com/article/facebookdata-privacy-scandal-a-cheat-sheet/

[34] Stoldt, Till-Reimer. (2019). Wie muslime die Schulen in Deutschland verändern. Welt, retrieved from May 1, 2019, at 19:55 WIB. https://www.welt.de/regionales/nrw/article189399185/Bildungspolitik -Wie-muslime-die-Schulen-veraendern.htm

[35] Twitter. About your activity dashboard. Retrieved from March 29, 2019, at 11:24 WIB. https://help.twitter.com/en/managing-youraccount/using-the-tweet-activity-dashboard 
[36] Welchering, Peter. (2019). Datenschützer alarmiert: Wie Facebook Kritiker überwacht. Zweites Deutsches Fernsehen (ZDF), retrieved from 7 Mei 2019, at 17:34 WIB. https://www.zdf.de/nachrichten/heute/wie-facebook-kritikerueberwacht-102.html\#xtor=CS5-48

[37] Wermelskirchen, Axel. (2016). „Unwort des Jahres“: Der gute alte Gutmensch ist zurück. Frankfurter Allgemeine Zeitung, retrieved from May 13, 2019, at 20:57 https://www.faz.net/aktuell/gesellschaft/unwort-des-jahres-dergutmensch-ist-zurueck-14010334.html

[38] Wizorek, Anne. (2014). Weil ein \#Aufschrei nicht reicht: für einen Feminismus von heute. Frankfurt am Main: Fischer. 